\title{
Why should we care about soil fauna?
}

\author{
Jonathan Michael Anderson(1) \\ (1)University of Exeter, School of Biosciences, Exeter EX4 4PS, UK. E-mail: j.m.anderson@exeter.ac.uk
}

\begin{abstract}
The reasons why we care about soil fauna are related to their intrinsic, utilitarian and functional values. The intrinsic values embrace aesthetic or moral reasons for conserving below-ground biodiversity. Unfortunately, the protection of soil invertebrates has rarely been a criterion for avoiding changes in land use and management. Utilitarian, or direct use values, have been investigated more extensively for fungi, bacteria and marine invertebrates than for soil fauna. However, some traditional remedies, novel enzymes and pharmaceutical compounds have been derived from earthworms, termites and other groups, and gut symbionts may provide microbial strains with interesting properties for biotechnology. The functional importance of soil invertebrates in ecosystem processes has been a major focus of research in recent decades. It is suggested herein that it is rarely possible to identify the role of soil invertebrates as rate determinants of soil processes at plot and ecosystem scales of hectares and above because other biophysical controls override their effects. There are situations, however, where the activities of functional groups of soil animals, even of species, are synchronised in space or time by plant events, resource inputs, seasonality or other perturbations to the system, and their emergent effects are detectable as higher order controls.
\end{abstract}

Index terms: biodiversity, biological preservation, ecosystem processes, functions of soil fauna, scales.

\section{Por que devemos nos importar com a fauna do solo?}

Resumo - As razões porque nos importamos com a fauna do solo estão relacionadas com seus valores intrínsecos, utilitários e funcionais. Os valores intrínsecos abrangem razões morais ou estéticas para conservar a biodiversidade subterrânea. Infelizmente, a proteção dos invertebrados do solo raramente tem sido um critério para evitar mudanças no manejo e uso da terra. Valores utilitários, ou de uso direto, têm sido pesquisados mais extensamente para fungos, bactérias e invertebrados marinhos do que para a fauna do solo. Contudo, alguns remédios tradicionais, enzimas novas e produtos farmacêuticos têm sido derivados de minhocas, cupins e outros grupos, e os simbiontes intestinais podem prover estirpes microbianas com propriedades interessantes para a biotecnologia. A importância funcional dos invertebrados edáficos nos processos ecossitêmicos tem sido foco de muita pesquisa em décadas recentes. Se sugere que raramente é possível identificar o papel dos invertebrados edáficos como determinantes de processos edáficos em escala de parcela e ecossistema (hectares) e em maiores escalas porque outros controles biofísicos superam seus efeitos. Porém, existem situações em que as atividades de grupos funcionais da fauna edáfica, ou mesmo de algumas espécies, estão sincronizadas no espaço ou no tempo com eventos vegetais, entrada de recursos, sazonalidade ou outras perturbações ao sistema, e seus efeitos emergentes são detectáveis como controles de ordem superior.

Termos para indexação: biodiversidade, preservação biológica, processos ecossistêmicos, funções da fauna edáfica, escalas.

\section{Introduction}

The reasons why we care about soil animals reflect our interests and personal circumstances. In responding to the invitation to address this theme, therefore, this review does not address the soil ecology literature that others have covered extensively (Lavelle et al., 2006; Barios, 2007; Brussaard et al., 2007; Huhta, 2007; Coleman, 2008). Rather, it indulges in more personal reflections on the topic, as implied by the title.
It is gratifying to see the ongoing interest in studying soil fauna of new generations of soil ecologists driven by the same fascination that motivated research by those before. During the last 40 years there has been a shift from a focus on studies of soil animal populations and communities, through microcosm experiments investigating processes and mechanisms of animal/ microbial interactions to a current emphasis on soil biodiversity and functioning at ecosystem scales. From a personal perspective, attempts to upscale soil 
fauna activities into ecosystem-level processes appear to have reached a 'glass ceiling': the goal is visible, but there appear to be conceptual and practical barriers to progressing through it without discarding some of the interesting ecological details that have motivated the attempt. Reasons why this is proving an intractable problem are considered below. However, this review will first address the 'why?' in terms of intrinsic reasons and utilitarian reasons before considering the functional roles of soil fauna.

\section{Intrinsic reasons to study soil fauna}

An intrinsic reason for studying soil fauna is its aesthetic value. Many soil ecologists started their careers as a child, turning over stones, rotten logs or piles of leaves, and catching macrofauna in jars to see who ate what and whom. Later into the careers, the light and electron microscopes revealed the extraordinary diversity of taxonomic groups and morphologies that has been an impetus for curiosity-driven, fundamental research into life histories, adaptations to life in soil, feeding ecology, decomposition processes and invertebrate interactions with microorganisms. The use of gelatine-embedded sections of woodland soils (Anderson \& Healey, 1970) provided a revelation into the structure of an organic soil: the microscopic complexity of the litter and soil microhabitats occupied by oribatid mites, mycorrizas with the mass of extra-matrical hyphae ramifying through the organic matrix, and occasional wonders such as a geophilid centipede brooding its eggs, or a pseudoscorpion with a collembola still in its chelicerae! Studies of this type have a very strong influence on one's approach when considering the scales at which animal/microbial interactions occur. This was reinforced by experiments on the dynamics of collembola (Folsomia candida) and a fungus (Mucor plumbeus) in two-dimensional or three-dimensional glass bead matrices (Leonard \& Anderson, 1991). In the 2-D system, intense grazing and rapid population growth of Folsomia rapidly exceeded fungal production and the collembola died out. In the 3-D system, both components persisted for some time and the fungus even sporulated in some of the interstitial spaces that were inaccessible to the collembola. Egg canibalism by the collembola was also reduced, resulting in the population eventually exceeding the fungal resources. The lesson that can be learned from these experiments is that one has to be very cautious in interpreting the results of experiments investigating animal/microbial interactions in laboratory systems, particularly where the structure of the matrix may expose fungi, plant roots or rhizosphere associations to artificial levels of grazing that may not occur in natural, undisturbed soils. This has been reinforced by the elegant studies of Nunan et al. (2002), which emphasise the importance of soil structure on the spatial and temporal dynamics of microbial populations, with important implications for their interactions with soil fauna.

\section{Soil fauna diversity}

The biodiversity of soil animal communities may exceed above-ground diversity by orders of magnitude in many habitats. The diversity of above-ground vegetation may influence below-ground diversity, but the mechanisms may be correlative rather than causal. Temperate woodlands dominated by single species of trees, such as beech (Fagus sylvatica) or oak (Quercus spp.), can contain 1,000 species $\mathrm{m}^{-2}$ (Schaefer \& Schauermann, 1990). The diversity of microhabitats in these organic soils appears to be a key determinant of the high microarthropod diversity (Anderson, 1978b), as well as to provide the substrate for food resources to support high micro-arthropod population densities. These organic soils can be formed by a single litter type that decomposes in more than a year, or by a combination of lower-quality and higher-quality litters, contributing to soil and litter habitat structure and food resources respectively. Conversely, high-quality litters that decompose rapidly only form ephemeral habitats for soil fauna. Manipulative experiments using litter types and species mixtures suggest, on the one hand, a strong influence of litter species on fauna diversity (Wardle et al., 2006) or, on the other hand, a predominant effect of litter types (Ilieva-Makulec et al., 2006). In both cases, general conclusions about these relationships may be limited by the relatively short-term duration of these experiments, which do not address the long-term effects of litter species and composition on the development of the underlying soil type that forms the main habitat for the soil fauna colonising surface litters.

Despite the increase in international awareness of the global extinctions of species, which resulted in the 1992 Convention on Biodiversity, the high diversity of below-ground communities should receive much 
wider recognition as a component of total system diversity (Hagvar, 1998; Decaëns et al., 2006). As yet, relatively few soil animals have been given IUCN Red Data Book status (e.g. Gippsland giant earthworm, Palouse earthworm, several ants and spiders; see http:// www.iucnredlist.org/ for details). Fortunately, public support for the conservation of pandas, tigers, gorillas and other megafauna also results in some preservation of their habitats, including the soils and associated below-ground diversity.

An interesting aspect of conservation is the occurrence of rare species. The history of exploitation, persecution or habitat destruction often accounts for the rarity of species in above-ground communities. However, rare species are also a feature of relatively undisturbed soil fauna communities and it is interesting to speculate as to how very low populations of some oribatid mites persist in the community. Firstly, conditions favouring an increase in their populations may occur only occasionally, so that, in most studies lasting a few years, one is recording only the remnants of declining populations. Secondly, species that are rare in soil may be abundant in above-ground habitats, such as bark (e.g. Humerobates spp.) or the canopy of trees (Winchester et al., 1999), and found incidentally when they fall to ground. Thirdly, some species are always rare because they have special food or habitat requirements that are intrinsically rare - though there is still little evidence for this since the paradox of niche differentiation was presented decades ago (Anderson, 1975). Fourthly, these species may be at the limits of their distribution range. Finally, there is the possibility that the standard sampling methods are inappropriate - as with the low incidence of phthiracarid nymphs, which are endophagous in twigs and leaf petioles and die in situ during heat gradient extraction. Whatever the causal mechanism, it might be revealing to repopulate defaunated soils in the field (Anderson, 1978a) with rare species, in order to monitor their population dynamics in the absence of competitors or predators.

\section{Utilitarian reasons for studying soil fauna}

Utility values cover the direct use of soil animals themselves (rather than their functions) as food, medicines or for novel biochemical products of pharmaceutical or industrial applications. Termites, earthworms, beetle larvae and other insects are foods of choice by hunter-gatherers all over the tropics. In many parts of Africa, pregnant women and children also have the habit of eating the soil sheeting produced by foraging Macrotermitinae (Walker et al., 1997). This is often regarded as just a tradition but, in fact, the termite-worked material is brought up from deep below the nutrient-depleted topsoil and is rich in available iron (that can reduce anemia), zinc (important for healing processes) and other trace elements that may be deficient in the diet (Walker et al., 1997). The termites can go many metres down to the parent material to locate the water Table during dry periods and the mineral content of the sheeting has also been used for bioprospecting for ores (Leroux \& Hambleton-Jones, 1991).

Soil microorganisms, especially the ones from extreme environments, have provided a wide variety of medicinal agents and biochemical compounds, such as thermostable enzymes (Cragg \& Newman, 2001), but relatively few novel compounds have been isolated from the soil fauna. Byzov et al. (1998) found compounds in the gut of millipedes that have strong bacteriolytic activity, but did not identify their specific nature. Mira \& Terezija (2007) have also shown that a glycoprotein extract of Eisenia fetida (Savigny, 1826) has numerous biological activities, including mitogenicity, anticoagulation, fibrinolysis, bacteriostasis and antioxidation. Some soil-feeding termites have an extraordinary digestive system that involves alkaline, anaerobic hydrolysis of soil organic matter, bacterial culture on the products, lysis of eubacteria by a complex of symbiotic actinomycetes, and absorption of the products through 'sieve pores' in the hindgut cuticle (Bignell et al., 1983). Characterisation of these actinomycete assemblages revealed a large number of Streptomyces strains that were unique gut associations (Bignell et al., 1991) and were assayed for novel metabolites by a pharmaceutical company (but with unknown results). These early studies of the termite gut microflora were limited by techniques for identifying microorganisms, such as spirochetes, that could be seen in electron micrographs but were unculturable. The use of new molecular sequencing techniques on a Nasutitermes species has now revealed an extraordinary diversity of gut symbionts and gene sequences for enzymes involved in lignocellulose and xylan hydrolysis (Warnecke et al., 2007), which could have biotechnological applications, including the development of second-generation biofuels. 
There may be many other examples that could be cited for the utility values of soil fauna. However, a keyword literature search for 'novel compounds' produced seven hits for termites, eight for earthworms and none for most other groups of soil fauna. In contrast, there were 71 hits for marine molluscs, 40 for corals, 94 for marine Crustacea and 341 for fish. Faulkner (1984) reviews the extensive range of natural products and metabolites of proven or potential commercial value obtained from marine invertebrates. Why is there this disparity for soil fauna communities that include representatives of many major Classes and Orders of invertebrates found in marine systems? Practical reasons for this may include the small size of most soil invertebrates and problems extracting sufficient mass for biochemical assays. However, a more fundamental reason may be that the cryptic nature of soil habitats provides protection from predation, so that the need for the defence compounds that are often of pharmaceutical interest is reduced. For example, many epigeic millipedes have aposematic colouring and defence compounds, including benzoquinones that are highly toxic and carcinogenic for mammals and birds. Nonetheless, some millipedes are used by capuchin monkeys to anoint their bodies to protect them against insects, such as mosquitoes and botflies (Valderrama, 2000; Weldon et al., 2003). Particularly toxic millipede species are so sought after that several monkeys may share a single individual (Valderrama, 2000).

The option values of soil fauna (the possibility of future use for economic purposes) is an important argument for conserving soil organism communities (Decaëns et al., 2006). Although a functional value, rather than a utility, the commercialisation of nematodes for controlling slugs (Glen \& Wilson, 1997) is an example of the largely untapped economic potential of soil fauna and illustrates the need for ongoing research into their ecology.

\section{Reasons for studying the functions of soil fauna}

There are many statements in the literature similar to that of Lavelle et al. (2006) that 'soil invertebrates play significant, but largely ignored, roles in the delivery of ecosystem services at plot and landscape scales'. Let us reflect on that: if the roles of soil invertebrates are significant, why are they 'ignored' by other soil scientists and practitioners? We know that the fauna and microorganisms are proximate determinants of soil biological processes. However, as measurements of ecosystem processes are made over larger spatial scales (hectares) and longer time intervals (months to years), process rates are related to more distal variables, such as vegetation type, soil biophysical properties ( $\mathrm{pH}$, soil mineralogy, etc.) and ultimately to climate. At these higher levels of process controls, the effects of soil organisms are rarely apparent. The same issues arise in relation to plant species diversity and net primary production at ecosystem or landscape scales.

Two main reasons for the difficulty of relating soil fauna activities to ecosystem services at plot and landscape scales may be: firstly, the top-down effects of management, notably in agricultural systems; secondly, the source and sink relationships of soil processes. These two situations will be considered before describing circumstances under which soil fauna activities can emerge as higher-order process controls.

\section{Agricultural management}

The 'top-down' effects of human activities (disposal of pollutants, forestry, agriculture, etc.) are generally deleterious to soil animal activity and biodiversity. Intensive agricultural practices involving high external inputs of energy (e.g., tillage) and agrochemicals, which are largely responsible for global food production, over-ride biological controls of soil processes and reduce soil fauna and microbial diversity. Nevertheless, soil biodiversity can be maintained or restored by organic farming practices; particularly by reduced or zero-tillage practices (Hendrix et al., 1986). An extensive study of organic farming practices by Birkhofer et al. (2008) showed that long-term organic farming using farmyard manure improved soil quality, increased soil microbial biomass, earthworm abundance and biological pest control. However, they conclude that grain and straw production were $23 \%$ higher in systems receiving mineral fertilisers and herbicides, reflecting the trade-off between productivity and environmental responsibility. Similarly, a study of forage production by an agricultural grassland in the UK during over 20 years (Clements et al., 1991) showed that the elimination of earthworms from plots treated with a fungicide resulted in changes in soil structure, bulk density, hydrologic properties, 
surface litter and soil organic matter dynamics - all the attributes that we associate with the importance of earthworm activities. However, grass production was significantly higher in the plots without earthworms, because the soil structure and fertility were not a constraint to herbage production in comparison to the effects of the fungal pathogen.

These examples suggest the need to be specific about the particular circumstances under which soil fauna can enhance plant growth and production, and that there are systems and scales where their activities may not be apparent to other stakeholders.

\section{Sink/source relationships of soil processes}

The net balance between sources and sinks of carbon, nutrients and hydrologic transfers determine whether the dynamics of a microsite, plot and ultimately the ecosystem are degrading (losing matter), aggrading (accumulating matter) or in approximate steady state. For example, net nitrogen mineralisation is the balance between $\mathrm{N}$-immobilisation ( $\mathrm{N}$-sinks) and gross $\mathrm{N}$-mineralisation ( $\mathrm{N}$-sources). Thus, if fauna feeding activities mobilise $\mathrm{N}$ within a resource where fungal immobilisation of $\mathrm{N}$ predominates, net $\mathrm{N}$ mobilisation will not be detectable using conventional methods. However, these dynamics of $\mathrm{N}$ mineralisation would be different if sampling was carried out at the micro-site scales at which the fauna or fungi affect soil processes or their 'functional domains' (Anderson, 2000). The same principles apply to surface water transfers of sediment. An earthworm cast, or an aggregation of casts beneath a tree, may be a source of sediment, but a biopore (e.g. an earthworm or termite burrow), a crack, a soil depression, a patch of mulch or a grass bund can form a sediment sink. Thus, whether a hill slope is eroding or not will depend on the balance of the processes producing and retaining soil fines. Van Hoof (1983) provides an elegant example of these processes for a woodland where different litter types and associated earthworm activities resulted in internal sediment transfers between exposed soil (under palatable litter) and sinks formed by accumulations of unpalatable litter. These patch dynamics resulted in some internal transfers of sediment, but no net losses across the woodland boundary. The same scaling issues occur if we try to relate soil fauna diversity and soil processes, because the two components have different relationships with increasing dimensions of space or time. Species richness increases as a cumulative function of sample number with stepwise increments where new communities are associated with some discontinuity, such as changes in vegetation cover. Carbon and nutrient fluxes, however, are the integration of sinks and sources for both biological and biophysical processes (including soil organic matter and mineral exchange sites that buffer nutrient cycles). So, under what conditions can soil fauna emerge as higher-order controls over soil processes? This is often most apparent where high population densities of a single species dominate a key functional group of 'ecosystem engineers', and when their populations are initiated or synchronised by some environmental trigger or event. An example of the former situation is the study by Elkins et al. (1986) in the Chihuahuan desert, where the long-term elimination of a subterranean termite, Gnathitermes tubiformans, changed the surface hydrology and resulted in changes in the distribution and type of vegetation cover. There are other examples in the literature of earthworms and termites effecting ecosystem-level processes, but often they can be explained by the second phenomenon of 'trophic synchronisation' that occurs in many natural and experimental situations but has been less explicitly recognised.

\section{Trophic synchronisation}

Much of our understanding of the roles of soil fauna in processes of decomposition, carbon mineralisation and nutrient cycling has been derived from laboratory microcosms, studies of decomposition using litter bags, manipulative field experiments, soil fauna invasions and introductions into new habitats. In each of these cases, the synchronisation of soil fauna activities amplifies the magnitude and the perception of their effects. Typically, when soil fauna are added to a microcosm with a base line of microbial activities, there is an increase in carbon or nutrient mineralisation rates after a short lag time, rising to a peak after a few days or weeks (depending on the animal biomass: resource ratio) followed by a slow decline to a new base line that may be above or below the control rates. The same response pattern occurred at field scale, such as when lumbricid earthworms were introduced into New Zealand pastures. This resulted in a large initial increase in grass production as a consequence of thatch incorporation and improved rooting depth, but fell to a lower sustained level after a few seasons (Stockdill, 1982). This 'wave front' pattern of activity 
is also typical for the effects of animal invasions or pest outbreaks, and with the system reaching a new equilibrium as resource limitations, competition and predation start to limit the pest population. This is also a reason why the results of microcosm experiments should be interpreted with caution, because the processes of immigration and emigration are prevented by enclosed systems. This not only prevents the natural succession of faunal and microbial species, but also the balance between animal populations and their food resources. Preventing dispersal can cause a 'pigsty' effect in which animals may be forced into coprophagy, higher feeding intensities on suboptimal foods or other unnatural trophic behaviours, resulting in artificially elevated process rates.

Soil fauna activities are also synchronised by some environmental events. For example, the placement of litter bags or mulches forms a defined cohort of material resulting in a succession of fauna and feeding activities that would be difficult to quantify in unenclosed litter. Similarly, trophic synchronisation occurs where patches of resources, such as mulches or dung, are deposited on the soil surface and cause temporary aggregations of soil fauna. These persist as long as the resource can be exploited, so that the larger the resource and the longer its duration, the greater the effects that soil fauna have on the structure of the underlying soil. This relationship is particularly marked for wood-feeding Macrotermitinae, for which the exploitation of a large dead tree over a long period can result in the creation of large tunnels that act as water conduits. Similarly, aggregations of earthworms beneath dung pats in a pasture significantly increased porosity and surface water infiltration rates (Knight et al., 1992). As the dung pat disintegrated, the earthworms dispersed and the soil pores they created infilled with soil particles and were occluded through trampling by the cattle. Hence, there was a dynamic mosaic of aggrading and degrading macropore patches in the pasture determined by the cattle's stocking density and feeding rates.

In all these cases, it is the transition in process rates from one state to another that enables us to identify the 'signal' of specific faunal effects against the background 'noise' produced by general functioning of the soil fauna and microbial community. Ecosystem engineers, notably earthworms and termites, are special cases in which the cumulative, physical effects of their feeding and burrowing activities can significantly affect soil structure and hydrology (as mentioned above). Again, the clearest examples of ecosystem engineers affecting soil properties and processes are in 'non-equilibrium' situations in which their populations are aggregated by localised food resources (mulches, litter, dung) or their activities have a defined initiation caused by introductions, invasions or their elimination.

\section{Conclusions}

The present paper has explored the reasons why soil fauna is studied in terms of their intrinsic, utilitarian and functional values. Intrinsic reasons alone justify research into these diverse and complex communities, and their conservation through habitat protection and appropriatelandmanagement practices to meet the needs of future generations. It is proposed that the functional importance of soil fauna remains a paradox because, on the one hand, extensive research has shown that they have significant effects on soil biophysical processes at the scales at which the organisms are active, but, on the other hand, these effects are rarely apparent at plot and ecosystem scales. Three mechanisms are proposed to explain this paradox. Firstly, that in highly diverse communities the 'signal' of particular soil fauna effects is masked by the 'noise' from other biophysical events that contribute to the same properties and processes (e.g. carbon and nitrogen mineralisation, soil structure and hydrologic fluxes). Secondly, that many processes created by soil fauna have 'sink' and 'source' dynamics that can nullify the signal of these local effects at larger spatial scales. Thirdly, that at large temporal and spatial scales, biophysical parameters are used as rate determinants of ecosystem processes and the structure of above or below-ground communities is rarely invoked. There are, however, circumstances in which the ecosystems are in transitional states, or in which environmental events synchronise with soil fauna activities, when roles of soil fauna become apparent at the plot and ecosystem level. Further research into these processes could define situations in which soil fauna are key determinants of ecosystem processes, and gain wider recognition of the functional importance of soil fauna by other disciplines.

\section{References}

ANDERSON, J.M. Competition between two unrelated species of soil Cryptostigmata (Acari) in experimental microcosms. Journal of Animal Ecology, v.47, p.787-803, 1978a. 
ANDERSON, J.M. Food web functioning and ecosystem processes: problems and perceptions of scaling. In: COLEMAN, D.C.; HENDRIX, P.F. (Ed.). Invertebrates as webmasters in ecosystems. Wallingford: CABI Publishing, 2000. p.3-24.

ANDERSON, J.M. Inter- and intra-habitat relationships between woodland Cryptostigmata species diversity and the diversity of soil and litter microhabitats. Oecologia, v. 32, p.341-348, 1978b.

ANDERSON, J.M. The enigma of soil animal species diversity. In: VANEK, J. (Ed.). Progress in soil zoology. Prague: Academia, 1975. p.51-58.

ANDERSON, J.M.; HEALEY, I.N. Improvements in the gelatine embedding technique for woodland soils. Pedobiologia, v.10, p.108-120, 1970.

BARIOS, E. Soil biota, ecosystem services and land productivity. Ecological Economics, v.64, p.269-285, 2007.

BIGNELL, D.E.; ANDERSON, J.M.; CROSSE, R. Isolation of facultatively aerobic actinomycetes from the gut, parent soil and mound materials of the termites Procubitermes aburiensis and Cubitermes severus. FEMS Microbiology Ecology, v.85, p.151-160, 1991.

BIGNELL, D.E.; OSKARSSON, H.; ANDERSON, J.M.; WOOD, T.G. Structure, microbial associations and function of the so-called "mixed segment" of the gut in two soil-feeding termites, Procubitermes aburiensis and Cubitermes severus (Termitidae, Termitinae). Journal of Zoology, v.201, p.445-480, 1983.

BIRKHOFER, K.; BEZEMER, T.M.; BLOEM, J.; BONKOWSKI, M.; CHRISTENSEN, S.; DUBOIS, D.; EKELUND, F.; FLIESSBACH, A.; GUNST, L.; HEDLUND, K.; MADER, P.; MIKOLA, J.; ROBIN, C.; SETALA, H.; TATIN-FROUX, F.; VAN DER PUTTEN, W.H.; SCHEU, S. Long-term organic farming fosters below and aboveground biota: implications for soil quality, biological control and productivity. Soil Biology \& Biochemistry, v.40, p.2297-2308, 2008.

BRUSAARD, L.; DE RUITER, P.C.; BROWN, G.G. Soil biodiversity for agricultural sustainability. Agriculture, Ecosystems and Environment, v.121, p.233-244, 2007.

BYZOV, B.A.; KURAKOV, A.V.; TRETYAKOVA, E.B.; THANH, V.N., RABINOVICH, Y.M. Principles of the digestion of microorganisms in the gut of soil millipedes: specificity and possible mechanisms. Applied Soil Ecology, v.9, p.145-151, 1998.

CLEMENTS, R.O.; MURRAY, P.J.; STURDY, R.G. The impact of 20 years' absence of earthworms and three levels of $\mathrm{N}$ fertilizer on a grassland soil environment. Agriculture, Ecosystems and Environment, v.36, p.75-85, 1991.

COLEMAN, D.C. From peds to paradoxes: linkages between soil biota and their influences on ecological processes. Soil Biology \& Biochemistry, v.40, p.271-289, 2008.

CRAGG, G.M.; NEWMAN, D.J. Natural product drug discovery in the next millennium. Pharmaceutical Biology, v.39, p.8-17, 2001.
DECAËNS, T.; JIMENEZ, J.J.; GIOIA, C.; MEASEY, G.J.; LAVELLE, P. The values of soil animals for conservation biology. European Journal of Soil Biology, v.42, p.23-38, 2006.

ELKINS, N.Z.; SABOL, G.V.; WARD, T.J.; WHITFORD, W.G. The influence of subterranean termites on the hydrological characteristics of a Chihuahuan desert ecosystem. Oecologia, v.68, p.521-528, 1986.

FAULKNER, D.J. Marine natural products and metabolites of marine invertebrates. Natural Product Reports, v.1, p.551-598, 1984.

GLEN, D.M.; WILSON, M.J. Slug-parasitic nematodes as biological control agents for slugs. Agro Food Industry Hi-Tech, v.8, p.23-27, 1997.

HAGVAR, S. The relevance of the Rio-Convention on biodiversity to conserving the biodiversity of soils. Applied Soil Ecology, v.9, p.1-7, 1998.

HENDRIX, P.F.; PARMELEE, R.W.; CROSSLEY, D.A.; COLEMAN, D.C.; ODUM, E.P.; GROFFMAN, P.M. Detritus food webs in conventional and no-tillage agroecosystems. Bioscience, v.36, 374-380, 1986.

HUHTA, V. The role of soil fauna in ecosystems: a historical review. Pedobiologia, v.50, p.489-495, 2007.

ILIEVA-MAKULEK, K.; OLEJNICZAK, I.; SZANSER, M. Response of soil micro- and mesofauna to diversity and quality of plant litter. European Journal of Soil Biology, v.42, p.244-249, 2006.

KNIGHT D.; ELLIOTT, P.W.; ANDERSON, J.M.; SCHOLEFIELD, D. The role of earthworms in managed, permanent pastures in Devon, England. Soil Biology \& Biochemistry, v.24, p.1511-1517, 1992.

LAVELLE, P.; DECAËNS, T.; AUBERT, M.; BAROT, S.; BLOUIN, M.; BUREAU, F.; MARGERIE, P.; MORA, P.; ROSSI, J-P. Soil invertebrates and ecosystem services. European Journal of Soil Biology, v.42, p.3-15, 2006.

LEONARD, M.A.; ANDERSON, J.M. Growth dynamics of collembola (Folsomia candida) and a fungus (Mucor plumbeus) in relation to nitrogen availability in spatially simple and complex laboratory systems. Pedobiologia, v.35, p.163-173, 1991.

LEROUX, J.P.; HAMBLETON-JONES, B.B. The analysis of termite hills to locate uranium mineralization in the Karoo Basin of South Africa. Journal of Geochemical Exploration, v.41, p.341-347, 1991.

MIRA, G.; TEREZIJA, H. Glycolipoprotein extract of Eisenia foetida (G-90): a source of biological active molecules. European Journal of Soil Biology, v.43, p.104-109, 2007.

NUNAN, N.; WU, K.L.; YOUNG, I.M.; CRAWFORD, J.W.; RITZ, K. In situ spatial patterns of soil bacterial populations, mapped at multiple scales, in an arable soil. Microbial Ecology, v.44, p.296-305, 2002.

SCHAEFER, M.; SCHAUERMANN, M. The soil fauna of beech forests: comparison between a mull and mor soils. Pedobiologia, v.34, p.299-314, 1990.

STOCKDILL, S.M.J. Effects of introduced earthworms on the productivity of New Zealand pastures. Pedobiologia, v.24, p.29-35, 1982. 
VALDERRAMA, X.; ROBINSON, J.G.; ATTYGALLE, A.B.; EISNER, T. Seasonal anointment with millipedes in a wild primate: a chemical defense against insects? Journal of Chemical Ecology, v.26, p.2781-2790, 2000.

VAN HOOF, P. Earthworm activity as a cause of splash erosion in a Luxembourg forest. Geoderma, v.31, p.195-204, 1983.

WALKER, A.R.P.; WALKER, B.F.; SOOKARIA, F.I.; CANNAN, R.J. Pica. Journal of the Royal Society for the Promotion of Health, v.117, p.280-284, 1997.

WARDLE, D.A.; YEATES, G.W.; BARKER, G.M.; BONNER, K.I. The influence of litter diversity on decomposer abundance and diversity. Soil Biology \& Biochemistry, v.38, p.1052-1062, 2006.

WARNECKE, F.; LUGINBUEHL, P.; IVANOVA, N.; GHASSEMIAN, M.; RICHARDSON, T.H.; STEGE, J.T.; CAYOUETTE, M.; MCHARDY, A.C.; DJORDJEVIC, G.; ABOUSHADI, N.; SOREK, R.; TRINGE, S.G.; PODAR,
M.; MARTIN, H.G.; KUNIN, V.; DALEVI, D.; MAJESKA, J.; KIRTON, E.; PLATT, D.; SZETO, E.; SALAMOV, A.; BARRY, K.; MIKHAILOVA, N.; KRYPIDES, N.C.; MATSON, E.G.; OTTESON, E.A.; ZHANG, X.; HERNANDEZ, M.; MURILLO, C.; ACOSTA, L.G.; RIGOUTSOS, I.; TAMAYO, G.; GREEN, B.D.; CHANG, E.C.; RUBIN, E.M.; MATHUR, E.J.; ROBERTSON, D.E.; HUGENHOLTZ, P.; LEADBETTER, J.R. Metagenomic and functional analysis of hindgut microbiota of a wood-feeding higher termite. Nature, v.450, p.560-565, 2007.

WELDON, P.J.; ALDRICH, J.R.; KLUN, J.A.; OLIVER, J.E.; DEBBOUN, M. Benzoquinones from millipedes deter mosquitoes and elicit self-anointing in capuchin monkeys (Cebus spp.). Naturwissenschaften, v.90, p.301-304, 2003.

WINCHESTER, N.N.; BEHAN-PELLETIER, V.; RUIZ, R.A. Arboreal specificity, diversity and abundance of canopy-dwelling mites (Acari, Oribatida). Pedobiologia, v.43, p.391-400, 1999.

$\overline{\text { Received on September 29, } 2008 \text { and accepted on July 11, } 2009}$ 